\title{
CHLORIS CASAGRANDE JUSTEN: VERSOS DE MEMÓRIA E RESISTÊNCIA
}

\author{
Vanessa Micheli Faraom Zanesco \\ Mestre em Letras pela UNIOESTE \\ vanessafaraom@hotmail.com
}

\section{RESUMO}

Este estudo tem por objetivo investigar representações da memória nos textos poéticos da escritora Chloris Casagrande Justen (1923), que exprime uma linguagem marcada pela subjetividade de suas palavras. Nos poemas selecionados das obras Jogo de luz (1993) e Essências transfiguradas (2011), a memória não convém como caráter informativo, mas prima pelo envolvimento de rememorar fatos que permaneceram em outro tempo, fazendo refletir sobre a realidade que foi sensoriada para constituir as imagens, a memória lírica e social, as quais revelam a nostalgia recorrente nos versos justinianos. O tema da memória coletiva e individual, que envolve o atavismo e a resistência, aparece para reforçar ainda mais a presença do recordar.

Palavras-chave: Memória, Poesia, Chloris Casagrande Justen.
Este estudio tiene por objetivo investigar representaciones de la memoria en los textos poéticos de la escritora Chloris Casagrande Justen (1923), que exprime un lenguaje marcada por la subjetividad en sus palabras. En los poemas seleccionados de las obras Jogo de luz (1993) y Essências transfiguradas (2011), la memoria no conviene como carácter informativo, pero prima por el envolvimiento de rememorar hechos que permanecerán en otro tiempo, haciendo reflejar sobre la realidad que fue sentida para constituir las imágenes, la memoria lírica y social, las cuales revelan la nostalgia recurriente en los versos justinianos. El tema de la memoria colectiva e individual, que envuelve el atavismo y la resistencia, aparece para reforzar aún más la presencia del recordar.

Palavras-clave: Memoria, Poesía, Chloris Casagrande Justen.

\section{RESUMEN}

\section{INTRODUÇÃO}

[...] o agora refaz o passado e convive com ele.

Alfredo Bosi (1977, p. 13)

O ser humano frequentemente se apoia nas lembranças dos outros, fazendo com que

pontos de referência façam submergir o passado. Objetos, costumes, músicas, ideias, 
palavras: esses instrumentos não foram inventados por um único ser, ele os emprestou de seu meio. Tendo como base a reflexão de Zilá Bernd (2013), pode-se afirmar que pela memória social um indivíduo pertence a uma determinada comunidade, pois, ao compartilhar lembranças e seguir tradições ao longo de muito tempo, ele não deixa seus antepassados no esquecimento.

Podemos entender que os conteúdos transportados são traços culturais, atos e agires, saberes e fazeres culturais que se unem e também transformam à medida que as memórias dos grupos dialogam e se misturam. Assim como Zilá Bernd, Ecléa Bosi também afirma que a memória é transportada pelos tempos:

Ao lado da história escrita, das datas, da descrição de períodos, há correntes do passado que só desaparecem na aparência. E que podem reviver numa rua, numa sala, em certas pessoas, como ilhas efêmeras de um estilo, de uma maneira de pensar, sentir, falar, que são resquícios de outras épocas. (BOSI, 1979, p. 33).

Nesse sentido, a literatura faz manter viva essa memória de outros tempos, as palavras fazem com que inúmeras vezes o passado e o presente se encontrem, e assim seja possível reviver tradições. Na poesia, é constante o processo da imaginação, que incide no desenvolvimento do pensar e as relações entre acontecimentos presentes e passados. Por meio da poesia, a linguagem é a testemunha da vida na medida em que o escritor faz a língua vibrar, e fende-a, arrasta-a e movimenta o pensamento em jogo infinito de luz e sombra.

Neste estudo, abordaremos a poesia de Chloris Casagrande Justen, poeta curitibana, que, de forma minuciosa e sensível, faz emergir muitos traços memorialísticos e culturais. Seus textos apresentam os temas por meio da linguagem simbólica, o processo que envolve a linguagem poética, os símbolos e a memória com um olhar diferenciado, olhar que, por sua 
vez, traz significados distintos para a poesia. Antonio Donizeti da Cruz (2010, p. 65) observa que “o poema é a metáfora do que o poeta sentiu e pensou. Essa metáfora é a ressureição da experiência e sua transmutação".

\section{A MEMÓRIA NOS VERSOS DE CHLORIS}

Os textos poéticos de Chloris Casagrande Justen apresentam imagens poéticas e símbolos que dão lastro à memória lírica e social por meio das palavras e da simbologia presentes na obra da escritora. Para tanto, é imprescindível salientar que "[...] a poesia é transcendência, contemplação, força que edifica e revigora o homem frente às vicissitudes da vida" (CRUZ, 2012, p. 66).

Dessa forma, a análise que envolve esse estudo atribui também importância aos textos poéticos como modo de elevação do pensamento. Quem escreve faz um pacto com a linguagem. Escrever é dar sentido à vida. É a própria vida que flui na escrita e faz com que o homem se redescubra e se reconheça no processo da criação. Criar é aligeirar, é descarregar a vida. É inventar novas possibilidades de vida, sendo que, por meio da memória, é possível reviver momentos e trazer outros significados para o que já foi vivenciado.

No poema "Contrastes", são perceptíveis os resquícios de outras épocas:

\section{CONTRASTES}

No meu peito a melodia

Canta canções sem palavras.

Há murmúrios ritmados

Em cantochões de mosteiros,

Silhuetas de outros tempos

Entre leques e minuetos 


\begin{abstract}
Há vozes roucas dolentes
Cantando chorados blues.

Há doídos banzos lentos,

Lamentos em fados tristes,

Belos arpejos trinados,

Um mundo rico de sons!
\end{abstract}

No meu peito há nuvens róseas

E nimbos de tempestades.

Há sons de sinos e timbales

Em catedrais submersas.

Há sonetos de Verlaine

E noturnos de Chopin,

Acordes de Debussy,

E sonatas de Beethoven.

Um som contínuo de Bach

Em cortejos de Dario.

"Tão longe", de Carlos Gomes,

Embala as dores de amor.

Por que meu verso espontâneo

Não é cascata ao luar?

(JUSTEN, 2011, p. 65).

Os versos ritmados do poema embalam a canção elaborada da poeta. No segundo verso, compreendemos que não são necessárias as palavras para embalar as canções, bastam os diversos sons que aparecem para despertar a memória que é referenciada desde o início. Para Halbwachs (1990, p. 29), "recorremos a testemunhos para reforçar ou enfraquecer e também para completar o que sabemos de um evento sobre o qual já temos alguma informação".

No texto poético, os minuetos trazem uma tradição francesa, os chorados blues e banzos tristes compõem mais uma melodia nas lembranças do sujeito poético. A mistura de 
sons e culturas diferentes tem continuidade na segunda estrofe: Verlaine, Chopin, Debussy, Beethoven, Bach e Carlos Gomes, poeta, pianista, compositores, músicos; grandes artistas de outras épocas são rememorados no texto:

Ora, o 'tempo' a que remete o discurso, o tempo das mediações predicativas, é um tempo originariamente social. Social porque intersubjetivo, social porque habitado pelas múltiplas relações entre pessoa e pessoa, pessoa e coisa. E social, em um plano histórico maior, isto é, determinado, de cada vez, por valores de família, de classe, de status, de partido, de educação, sobretudo de educação literária, de gosto. O tempo histórico é sempre plural: são várias as temporalidades em que vive a consciência do poeta e que, por certo, atuam eficazmente na rede de conotações do seu discurso. (BOSI, 1977, p. 121, grifo do autor).

Essa memória lírica e social apresentada nos versos é fundamental para sua própria descoberta enquanto poeta. A chuva de sons apresentada no poema leva o leitor para lugares e tempos distantes, muitas vezes também para o desconhecido. A memória individual e coletiva são misturadas pelo sujeito poético. Nas palavras de Michael Pollak:

Quais são, portanto, os elementos constitutivos da memória, individual ou coletiva? Em primeiro lugar, são os acontecimentos vividos pessoalmente. Em segundo lugar, são os acontecimentos que eu chamaria de 'vividos por tabela', ou seja, acontecimentos vividos pelo grupo ou pela coletividade à qual a pessoa se sente pertencer. [...] Se formos mais longe, a esses acontecimentos vividos por tabela vêm se juntar todos os eventos que não se situam dentro do espaço-tempo de uma pessoa ou de um grupo. (POLLAK, 1992, p. 202, grifos do autor).

As referências históricas são refletidas por grandes artistas de muitas gerações que são destacados no poema, remetendo a uma memória coletiva que parte da memória individual. Ao finalizar o poema vemos o questionamento da poeta "Por que meu verso 
espontâneo/ Não é cascata ao luar?", demonstrando o desejo de que seus versos embalem os pensamentos do leitor.

Por meio da memória é possível o passado agir no presente. Halbwachs (1990) nos aponta que, a partir das vivências em grupo, a memória pode ser reconstruída. No poema "Férias no Planalto Central", é perceptível essa reconstrução:

\section{Férias no Planalto Central}

Viagem dos Desembargadores

do Tribunal de Justiça do Paraná

e suas famílias, à Brasília. 1970

No planalto central do torrão brasileiro

Cantando belezas, louvando valores,

Passeia e descansa, risonho e feliz,

Um grupo sulino, que julga, encantado.

$[\ldots]$

Seus olhos conservam tão caras lembranças:

A taça gigante do rico pinheiro,

A verde floresta de escuros matizes,

A jovem e bela Cidade-Sorriso.

[...]

Gravar as minúcias da viagem notável,

É anseio de todos em cada lugar.

A uns é o povo que encanta e surpreende,

A outros, as cores, o rio, a folhagem.

[...]

Que igreja imponente na praça florida.

$\mathrm{O}$ sol aquecendo o repuxo e a flor,

A torre bordada louvando a fartura

Que leva Uberlândia à vanguarda de Minas. 


\section{$[\ldots]$}

Nas ruas estreitas que sobem e descem,

Retrato perfeito da antiga Colônia,

Outro Preto tem mais de riqueza na arte

Do que na quantia do outro a brilhar.

Nos olhos, o passado com rendas e dor;

Na mente, Marília e o amoroso Dirceu,

A ação destemida dos Inconfidentes,

Fazendo pulsar o amor ao Brasil.

\section{$[\ldots]$}

Cortando fazendas, no asfalto brilhante, Guardando nos olhos belezas sem fim, O viajante do Sul, ao som de cantigas, Já vive as delícias de Poços de Caldas.

\section{[...]}

O grupo sulino, com seus magistrados Trazendo consigo Anhanguera e Athaíde, Louvando Niemeyer e Francisco Lisboa, Conhece melhor, o Brasil, sua terra.

E vem comovido com a Pátria querida, Sonhando grandezas, criando esperanças De muitas tarefas de amor e venturas, Unidos na luta em prol da Justiça.

(JUSTEN, 1993, p. 104-110).

A viagem realizada pelos desembargadores do Paraná com suas famílias traz para o eu lírico muitas lembranças, ao mesmo tempo em que evidencia as belezas do Brasil. Segundo Paz (2012, p. 195), “o poeta não escapa à história, mesmo quando a nega ou a ignora. Suas experiências mais secretas ou pessoais se transformam em palavras sociais, 
históricas. Ao mesmo tempo, e com essas mesmas palavras, o poeta diz outra coisa: revela o homem".

É o caso do poema "Férias no Planalto Central": a viagem dos desembargadores está atrelada à história; o homem que conhece outras culturas, o encantamento que o grupo sente diante dos lugares é evidente e fica marcado no poema. A região de onde eles vêm, o Paraná, também é reverenciada: “A taça gigante do rico pinheiro,/ A verde floresta de escuros matizes,/ A jovem e bela Cidade-Sorriso". O contato com as pessoas que também viveram aquelas situações, ou com os lugares em que elas aconteceram, permite a rememoração daqueles fatos, numa relação entre memória individual e memória coletiva. Isso mostra que "a representação das coisas evocada pela memória individual não é mais que uma forma de tomarmos consciência da representação coletiva relacionada às mesmas coisas" (HALBWACHS, 1990, p. 61).

Nos versos "A uns é o povo que encanta e surpreende, / A outros, as cores, o rio, a folhagem", revela-se que o que cada um grava em sua mente é peculiar, que as impressões que cada um tem podem não ser as mesmas do outro. Esse fato é o que leva também à memória individual e coletiva, o que é notório por um ser e que depois pode ser dividido com outros a partir das experiências vividas. Na sequência, as imagens que passam pela retina do eu poético mostram o que se destacou das cidades pelas quais o grupo passou: a igreja imponente, a torre bordada, ruas estreitas, as fazendas, Poços de Caldas. Aqui, “diríamos voluntariamente que cada memória individual é um ponto de vista sobre a memória coletiva" (HALBWACHS, 1990, p. 51). 
A temática do poema explora a memória lírica, assim como também fica evidente o encantamento do sujeito poético diante de tantas belezas. O grupo sulino está conhecendo as belezas de muitos lugares do Brasil; juntos descobrem vários detalhes por onde passam. Entretanto, é necessário destacar que as impressões que cada um tem e guarda na sua memória é individual. Zilá Bernd, a partir de estudos de Halbwachs, tece comentários sobre a memória individual e coletiva:

[...] experiências mnemônicas, mesmo que vividas individualmente, como uma visita que fazemos pela primeira vez a uma determinada cidade, são coletivas na medida em que a experiência de outras pessoas participa desse encontro. M. Halbwachs nos ensina que, mesmo que tenhamos feito a viagem sozinhos, a memória é coletiva, já que, ao recordarmos as experiências ali vividas, o fazemos lembrando informações que nos foram transmitidas por pessoas que encontramos, por obras arquitetônicas ou pictóricas que foram elaboradas por determinado arquiteto ou pintor [...]. (BERND, 2013, p. 29).

Nesse caso, a experiência foi vivenciada coletivamente, mas o modo como cada um armazenou isso na sua lembrança e depois apresentou é distinto, o que remete à memória individual. Porém, o fato de ter absorvido informações por meio de outros indivíduos e culturas faz com que a memória se torne coletiva. A respeito disso, Bernd destaca que:

\footnotetext{
É bastante instigante a relação entre memória individual e memória coletiva, pois são os indivíduos que se lembram na medida em que fazem parte de um grupo. Mas as lembranças não aparecem da mesma forma a cada um deles, mesmo que as vivências tenham sido semelhantes [...] (BERND, 2013, p. 30).
}

Na última estrofe, evidencia-se o novo porvir desejado pelo eu lírico. Os lugares, pessoas e tradições que conheceu fizeram com que o anseio de sua nação ser melhor fosse aflorado "sonhando grandezas, criando esperanças". 
Em "Helena Kolody: presença infinita", a saudade e a admiração trazem versos de lembranças:

HELENA KOLODY: PRESENÇA INFINITA

Como posso falar de sua partida?

Continuo vendo o brilho azul

Do seu olhar profundo.

Continuo buscando sua voz,

No ritmo de sua poesia

Humana e bela.

Seu porte altivo e sereno

É tela renascentista

Nas minhas doces lembranças.

Quero viver o passado,

Encontrar a mestra, a deusa

Atena falando às andorinhas.

(JUSTEN, 2011, p. 53).

A consciência da saudade leva o eu poético a tencionar a tristeza recordada com o sentido da esperança do reencontro. O passado não se limita a ser recordado e se abre para o sentido da possibilidade, ampliando-se os horizontes vivenciais, uma vez que a memória desconhece margens.

O fato de querer reviver o passado ultrapassa uma noção limitada e lógico-sequencial do tempo, organizada por conexões exclusivamente materiais. Um modo de permanecer presente é ser lembrado após a morte, e é o que o sujeito poético faz ao relembrar a poeta curitibana Helena Kolody. A lembrança é pensada como "uma reconstrução do passado com a ajuda de dados tomados de empréstimo ao presente e preparados por outras 
reconstruções feitas em épocas anteriores", da qual "a imagem de outrora já saiu bastante alterada" (HALBWACHS, 1990, p. 91).

A admiração pela poeta curitibana fica clara nos versos de "Helena Kolody: presença infinita": a poesia "humana e bela", o porte "altivo e sereno" são algumas lembranças do sujeito poético, além o fato de chamá-la de mestra e deusa, o que reforça a enorme estima pela artesã da poesia mais uma vez.

Lembrar alguém que já não está no mundo material faz emergir em nós a consciência da finitude desta vida, a mobilizar o nosso desejo de permanência, que se inscreve no ato de lembrar e também de fazer lembrar. É o que nos parece estar, também, no sentido melancólico do texto. A única garantia de alguma persistência, frente às transformações provocadas pelo tempo, é o que resta na memória.

\section{ATAVISMO E RESISTÊNCIA}

De acordo com Bosi (1977), a lírica deve ser interpretada como resistência no sentido de confronto com a opressão e o sofrimento, e como nostalgia que propõe imagens positivas do passado. Quando se tem uma imagem muito positiva do passado, tem-se conteúdo para fazer uma crítica do presente e resquícios do passado submergirem. Por permanecer resistente ao "tempo", a poesia reveste-se de um papel social que interage com as expectativas de seus leitores, provocando também neles reflexões em torno de suas condições de existência.

No poema "Heróis de Cervantes", a memória atávica é evidenciada:

\section{Heróis de Cervantes}


Para Ivan, Márcio e Sérgio

De luzes e sombras caminhos se abrem.

São lindas veredas, são amplos jardins.

Nos jovens de hoje, iguais aos de ontem,

A mesma esperança, o mesmo vigor.

No grande alvoroço da busca incessante

O duro esgrimir do herói de Cervantes.

No brilho dos olhos - a firmeza do aço.

$\mathrm{Na}$ força do gesto - a vitória da ideia.

Assim decididos a vencer desafios

Os jovens de hoje, de cenhos cerrados,

Carregam consigo anseios e fé.

Buscando valores há muito sonhados.

Quisera que vissem o orvalhos da rosa,

A mão que semeia, a brisa a soprar.

Quisera que um céu sem nuvens ou sombras,

Cobrisse o forjar de um glorioso porvir.

(JUSTEN, 1993, p. 50).

A poeta Chloris Justen pinta com novas cores o herói de Cervantes. Para a escritora, fazer uma referência a este herói é uma forma de mostrar para a nova geração os valores que pode assumir. Vê-se o atavismo ao comparar, na primeira estrofe, os jovens de hoje e de ontem com esperança e vigor.

Fazer alusão a um romance tão conhecido como do herói de Cervantes faz com que o sonho e a realidade estejam presentes no mundo tal como é, e naquele que pode ser idealizado pelos jovens. Na terceira estrofe, a memória atávica pode ser claramente 
percebida no verso "buscando valores há muito sonhados", esses valores que vão passando de geração em geração e que podem ser evidenciados pelos jovens de hoje, pois:

Mesmo quando o poeta fala do seu tempo, da sua experiência de homem de hoje entre homens de hoje, ele o faz, quando poeta, de um modo que não é o do senso comum, fortemente ideologizado; mas de outro, que ficou na memória infinitamente rica da linguagem. O tempo "eterno" da fala, cíclico, por isso antigo e novo, absorve, no seu código de imagens e recorrências, os dados que lhe fornece o mundo de hoje, egoísta e abstrato. (BOSI, 1977, p. 112, grifos do autor).

Na última estrofe o sujeito poético revela seu desejo de um novo mundo, com novos ideais, com pessoas que oscilam entre sonhadores e realistas, que lutam pelas suas aspirações, talvez como aquele mundo sonhado pelo herói de Cervantes e o anseio do orvalho da rosa, da brisa a soprar e um céu sem nuvens e sombras para os jovens de agora.

Chloris, ao abordar o tema do Deus-Menino, tem, em "Peregrina", marcas atávicas:

\section{PEREGRINA}

A suave Maria Peregrina

No íngreme e triste caminho

Carrega um filho no ventre

Sonhando tê-lo nos braços.

As dores do parto bendito

Já cobrem seu rosto de suor.

Também um suor como sangue

Queima as faces de José.

O choro do Deus-Menino:

Lágrima que apaga as dores

Do corpo surrado do pai,

Da alma da Mãe Peregrina.

A Estrela dirige os Magos. 


\author{
A manjedoura e o Menino, \\ José, Maria e os pastores \\ São na gruta a humanidade. \\ Ano após anos, em séculos, \\ Homens e povos do mundo \\ Lentamente e em sofrimento, \\ Buscam a união do Natal. \\ Na trajetória humana, \\ A estrela é o Deus-Menino; \\ Misericórdia e Amor \\ É a prece da Peregrina. \\ (JUSTEN, 2011, p. 107).
}

Reviver a história do nascimento do Deus-Menino faz emergir no leitor resquícios desse momento que aconteceu há tantos e tantos anos. Da primeira a quarta estrofe a história é recontada, cada verso faz a imaginação ser ativada e visualizar cada cena que está sendo delineada. Esse sentimento de querer resgatar traços do passado, segundo Pollak, é:

A memória, essa operação coletiva dos acontecimentos e das interpretações do passado que se quer salvaguardar, se integra, como vimos, em tentativas mais ou menos conscientes de definir e de reforçar sentimentos de pertencimento e fronteiras sociais entre coletividades de tamanhos diferentes: partidos, sindicatos, igrejas, aldeias, regiões, clãs, famílias, nações etc. A referência ao passado serve para manter a coesão dos grupos e das instituições que compõem uma sociedade, para definir seu lugar respectivo, sua complementariedade, mas também as oposições irredutíveis. (POLLAK, 1989, p. 9).

No poema, o sujeito poético não quer tratar de alguma religião específica, mas mostrar que na história do nascimento do Deus-Menino é possível resgatar a fé na humanidade, o que fica claro na quinta estrofe do poema ao falar da busca da união do 
Natal, um momento representativo e significativo para muitos ainda, época do ano em que, geralmente, as pessoas buscam uma maior união com a família e amigos. Essa memória atávica resgatada pelo poema "Peregrina" traz lições de amor, faz as pessoas repensarem sua vida, e, ao olhar para esse nascimento, veem no Deus-Menino e na Peregrina a estrela, Misericórdia e Amor.

No texto "Resistência", a temática envolve o ato de perseverança e a aceitação do sujeito poético:

\section{Resistência}

- Aceita, disse o vento a assoviar,

Mesmo que a indiferença

Mais forte que o minuano,

Vergaste como um acoite.

- Aceita, disse o fogo a crepitar,

Na pura voz da razão,

Que profundo atinge a alma

Um sentido encontrarás.

- Aceita, disse o pássaro a cantar,

É na doação do amor

Que alcançarás harmonia

Para a aflição do teu ser.

- Aceita, disse a brisa a murmurar,

Só incontáveis murmúrios

A iluminar mil facetas

Hão de trazer tua paz.

- Aceita, disse a luz do arco-íris,

O tempo que célere passa

Transforma em vaga lembrança 
Todo o amargor que te fere.

Aceitar, indago aos céus!

Sem compreensão, sem carinho,

Sem afago, sem amor,

Como aceitar e viver?

(JUSTEN, 1993, p. 26-27).

A temática da resistência, assim como da luta, estão presentes nos versos desse poema. Por meio de elementos simbólicos, o sujeito lírico mostra que viver requer perseverança. Na elaboração densa de seu canto, o eu poético revela a agudeza da consciência, que corresponde a uma dor de viver ainda mais profunda, e também a sobrevivência do sujeito.

Para o crítico, Alfredo Bosi (1977), o termo resistência na poesia deve ser entendido como um mecanismo de resistência simbólica à opressão, subvertendo a ordem estabelecida por discursos ideologicamente dominantes e propondo implicitamente uma nova forma de organização social. Ainda de acordo com Bosi, a poesia deve revelar-se em duas dimensões necessárias ao entendimento de suas representações. Primeiramente, ela é o "ser" que comporta em si os elementos estéticos que a fazem existir enquanto tal, a saber, seus componentes sonoros, imagéticos e figurativos.

É nesse sentido que o poema "Resistência" se aplica a esse contexto, pois essa força de resistir às tempestades se opõe ao deixar-se vencer. A repetição do verbo "Aceita" em todas as estrofes enfatiza o jogo de ganhar e perder. O aceitar, no poema, não aparece no sentido de conformidade, pelo contrário, é o aceitar para pensar, observar e depois agir. 
Vários elementos aparecem em todas as estrofes para reforçar a ideia de resistência e mudança: vento, fogo, pássaro, brisa, arco-íris. O vento que pode indicar mudança, o fogo que transforma o objeto, o pássaro e a brisa que sugerem leveza, e ainda o arco-íris, um novo tempo.

$\mathrm{Na}$ última estrofe, o sujeito poético demonstra ainda confusão em relação a sua existência, indaga aos céus; sua resistência se faz presente no sentido de viver "Sem compreensão, sem carinho, / Sem afago, sem amor". E termina com um questionamento "Como aceitar e viver?", demonstrando também sua fragilidade diante da falta de sentimentos, por isso a dificuldade em aceitar e resistir.

Chloris Justen também utiliza da poesia como forma de homenagear:

\section{HOMENAGEM AO PROFESSOR}

Na construção do futuro

Há sementes germinando

Conosco, frutos maduros

Das muitas lavras passadas.

Nós somos o instante e o presente

Lavrando na sementeira,

Mudando a fronte das gentes

Que viverão o porvir.

Em cada face mudada,

A essência de nossa messe,

Marcando a força e o caráter

De um mundo de novos sóis.

No futuro do futuro

Seremos flores e frutos 
Vivendo em novas sementes

As bandeiras que plantamos!

(JUSTEN, 2011, p. 55).

Na fusão de todos os tempos - passado, presente e futuro - o eu lírico, movido por um grito de fraternidade, ao mesmo tempo em que presta homenagem aos professores, também trata do tema resistência, que fica marcado desde a primeira estrofe, uma vez que é o professor resistente ao tempo por meio dos frutos que plantou. Para Alfredo Bosi (1977, p. 191), "resistir é subsistir no eixo negativo que corre do passado para o presente; e é persistir no eixo instável que do presente se abre para o futuro".

Os três tempos verbais intercalam-se durante todo o poema. Esses tempos são expressos através da voz lírica que ocupa o lugar de professor ao utilizar a aproximação em relação ao que está sendo observado: "nós somos o instante e o presente" e ainda: "no futuro do futuro / Seremos flores e frutos". Isso demonstra que o eu lírico encontra-se totalmente envolvido com essa profissão: Professor.

A forma como o sujeito poético conduz as palavras é significativa e demonstra a estima por esses construtores do futuro, fazendo com que muitos professores se orgulhem da profissão. Os versos "Em cada face mudada,/ A essência de nossa messe,/ Marcando a força e o caráter/ De um mundo de novos sóis" reafirmam a capacidade que o professor tem de eternizar-se durante o tempo. Cada gesto, palavra, ensinamento que conseguiu passar pela esteira da vida de outros faz essa perpetuação. Na última estrofe, os signos flores e frutos são a metáfora da continuidade idealizada pelo eu poético.

No texto "Portais", o fazer poético enquanto resistência: 
PORTAIS

Sempre quis cantar beleza

Espargindo como brisa

Suaves, doces venturas.

Fazer do meu verso forte

O bálsamo e a esperança.

A angústia e o sofrimento,

A vida se incumbe deles,

Marcando a perda da inocência

À descoberta do ocaso.

Nascem flores entre as pedras.

Brilha o sol na madrugada.

Surge a bonança no caos.

Por que não cantar beleza

Abrindo portais de luz?

(JUSTEN, 2011, p. 25).

Alfredo Bosi (1977, p. 157) diz que "a arte resiste porque a percepção animista ainda é, ao menos para a infância e, em outro nível, para o poeta, uma fonte de conhecimento". Nesse sentido é que o poema "Portais" vai sendo esboçado. O eu poético deixa claro a dedicação e a preocupação com suas palavras "Fazer do meu verso forte/ O bálsamo e a esperança".

A segunda estrofe vem para mostrar que na vida há os momentos dolorosos, e a poesia existe para que um novo olhar aconteça:

A poesia leva o homem para fora de si e, simultaneamente, o faz regressar ao seu ser original: volta-o para si. O homem é a sua imagem: ele mesmo e aquele 
outro. Através da frase que é ritmo, que é imagem, o homem - esse perpétuo chegar a ser - é. A poesia é entrar no ser. (PAZ, 2012, p. 119)

A última estrofe apresenta um jogo dialético entre pedras versus flores, sol versus madrugada, bonança versus caos. É interessante pensar nessas antíteses utilizadas pelo eu lírico: enquanto a imagem da pedra dá a ideia de peso, algo sem vida, a flor remete a algo leve, a beleza, uma nova esperança, é a flor que surge mesmo diante da dificuldade de resistir à pedra. É essa beleza que os versos da poesia são capazes de trazer e a luz do sol surge quando tudo é escuridão. A beleza, a importância e a necessidade da poesia estão em cada detalhe:

Já disse que se nascesse um novo pensamento político, a influência da poesia seria indireta: lembrar certas realidades enterradas, ressuscitá-las e apresentá-las. Diante da questão da sobrevivência da espécie humana em uma terra envenenada e desolada, a resposta não poderia ser diferente. Sua influência seria direta: sugerir, inspirar e insinuar. Não demostrar, mas mostrar. (PAZ, 1993, p. 146).

É essa necessidade poética que se apresenta nos versos do poema "Portais". Essa influência do sugerir, inspirar e insinuar, teorizada por Paz, é desejada pelo eu poético do poema, ao fazer com que seus versos sejam interpretados e possam refletir de maneira sensível no leitor. Pois a poesia é isso, sensibilidade diante de cada signo poético escrito pelo artesão da palavra.

\section{CONSIDERAÇÕES FINAIS}

Para Alfredo Bosi (1977), a poesia é inerentemente histórica. Ela tem por mérito o poder de promover novas formas de percepção da vida em sociedade. Tudo isso graças ao poder criativo do poeta, esse artesão da palavra que consegue trazer para o interior da sua 
criação todos os movimentos perceptíveis da existência, desde os mais delicados até os de natureza trágica.

A maioria dos poemas da escritora que tratam da memória direciona a uma busca incessante de valores do passado e faz emergir a consciência da finitude desta vida, mobilizando o desejo de permanência, que se inscreve no ato de fazer lembrar. Não se trata apenas de reconstruir o passado no presente da recordação, mas de reconhecer que a memória instala uma incessante tensão com o futuro.

A memória tece e fortalece relações que de tão cotidianas passam despercebidas. Cada imagem, seja ela literária ou visual, se forma em torno de uma orientação fundamental que se compõe dos sentimentos próprios de uma cultura, assim como de toda a experiência individual e coletiva.

A poesia de Chloris Casagrande Justen traz experiências cotidianas, porém com uma visão peculiar em cada tema que é abordado. Sua poesia é multifacetada; por meio do canto gratuito e imagético pluralístico, os versos convidam o leitor a mergulhar na profundeza de cada palavra elaborada pela poeta. De uma maneira especial, essa artesã da palavra vê, sente e interpreta o mundo, conseguindo de maneira única dar cor e brilho para seus versos.

\section{REFERÊNCIAS}

BERND, Zilá. Por uma estética dos vestígios memoriais: releitura da literatura contemporânea das Américas a partir dos rastros. Belo Horizonte, MG: Fino Traço, 2013. BOSI, Alfredo. O ser e o tempo da poesia. São Paulo: Cultrix, 1977. BOSI, Ecléa. Memória e sociedade: lembranças de velhos. São Paulo: T.A Queiroz, 1979. 
CRUZ, Antonio Donizeti da. Helena Kolody: a poesia da inquietação. Marechal Cândido Rondon: Edunioeste, 2010.

2012.

O universo imaginário e o fazer poético de Helena Kolody. Cascavel: EDUNIOESTE,

HALBWACHS, Maurice. A Memória Coletiva. São Paulo: Vertice, 1990.

JUSTEN, Chloris Casagrande. Essências transfiguradas. 1. ed. Curitiba: Ed. dos autores, 2011. Jogo de luz. Curitiba: Artes e Textos, 1993.

PAZ, Octavio. O arco e a lira. São Paulo: Cosac Naify, 2012.

POLLAK, Michael. Memória e identidade social. Estudos históricos, Rio de Janeiro, v. 5, n.10, p. 200-212, 1992.

Artigo recebido em: 31 de maio de 2018. Artigo aprovado em: 17 de setembro de 2018. 